\author{
Lilla Moroz-Grzelak \\ Instytut Slawistyki PAN \\ Warszawa
}

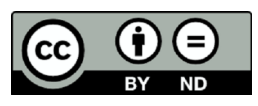

\title{
Kręgi zainteresowań problematyką macedońską w Polsce. Publikacje naukowe
}

Zarys treści: W tekście przedstawiono prace naukowe poświęcone Macedonii, jakie ostatnio opublikowano w Polsce. Odniesiono się do monografii Ireny Stawowej-Kawki, która ukazała procesy zachodzące w relacjach albańsko-macedońskich oraz do powstałego przy jej współautorstwie zbioru dokumentów prezentującego polsko-macedońskie stosunki dyplomatyczne z okresu 20 lat istnienia samodzielnej Republiki Macedonii. Omówiono też studium Krzysztofa Stępnika, obrazujące zainteresowanie tematyką macedońską na łamach polskiej prasy w przeszłości. Zwrócono uwagę na pracę Macieja Kawki i Pawła Płanety odzwierciedlającą amerykański i polski dyskurs prasowy o Macedonii w latach 1991-2012.

Outline of content: This article presents the academic literature dedicated to Macedonia recently published in Poland. This includes the monograph by Irena Stawowa-Kawka, in which she details the processes occurring in Albanian-Macedonian relations, and the co-authored collection of documents portraying the Polish-Macedonian relations spanning over two decades of existence of the independent Republic of Macedonia. Also discussed is the study by Krzysztof Stępnik characterising the interest in Macedonian matters shown in the past by the Polish press. And finally, the article refers to the study by Maciej Kawka i Paweł Płaneta, which reflects the discourse regarding Macedonia in the American and Polish press in the years 1991-2012.

Slowa kluczowe: relacje polsko-macedońskie, stosunki albańsko-macedońskie, Macedonia w prasie polskiej, tożsamość macedońska

Key words: Polish-Macedonian relations, Albanian-Macedonian relations, Macedonia in the Polish press, Macedonian identity

Pretekstem do podjęcia tematu o kręgach ujmujących zagadnienia związane z Macedonią w Polsce stała się odpowiedź redakcji pewnego poczytnego dziennika o rezygnacji - pod pretekstem niszowości tematyki - z opublikowania w jej dodatku kulturalnym wywiadu z uznanym i docenianym na świecie macedońskim pisarzem, którego kolejna, nagrodzona książka ukazała się w przekładzie na język 
polski ${ }^{1}$. Może to wskazywać na brak prasowego zainteresowania problematyką macedońską w okresie ciszy i spokoju, kiedy nie docierają stamtąd żadne informacje o poruszających opinię publiczną wydarzeniach. Tym samym można domniemywać, że tematyka macedońska bywa przedstawiana na łamach polskiej prasy tylko wtedy, gdy coś się dzieje na jej obszarze. Odpowiedź redakcji poczytnej gazety kieruje jednocześnie uwagę na zupełnie inny obieg publikacji i wydawnictw, które zajmują się sprawami macedońskimi - w przeciągu zaledwie dwóch lat ukazały się w Polsce ważne prace naukowe, poświęcone niezgłębianym dotąd zagadnieniom związanym z Macedonią, przynosząc przy tym wnikliwe analizy, jakie mogą mieć przełożenie także współcześnie i do tego w zupełnie innych częściach Europy.

Pierwsza z nich zdaje się dokumentować zjawisko „niszowości” tematyki macedońskiej w prasie polskiej, kiedy podejmowano ją w okresie znaczących dla jej obszaru wydarzeń. Jest nią monografia Macedonia w prasie polskiej (1903-1914), autorstwa prasoznawcy, badacza publicystyki politycznej i dyskursu prasowego w Polsce, Krzysztofa Stępnika². To książka niezwykle cenna, która, choć w tytule ogranicza się do wybranego okresu z macedońskich dziejów, to dokumentuje zjawisko szersze, jakim jest nośność pewnych tematów i budzenie zainteresowania odbiorcy sprawami odległymi od Polski, a także sposobami ich przedstawiania przez dziennikarzy i komentatorów. Jest przy tym gruntownym studium naukowym ujawniającym mechanizmy, w jaki sposób, kto, kiedy, dlaczego oraz z jakich powodów dany temat bierze na swój warsztat.

Analiza polskich publikacji prasowych przeprowadzona przez K. Stępnika pokazuje, iż recepcja spraw macedońskich dokonywała się na wielu zmiennych płaszczyznach, gdyż zarysowała się znaczna różnica nie tylko pomiędzy intensywnością pisania o nich w latach 1903, 1908 i 1912-1913, ale także w sposobie informowania i przedstawiania faktów. Obrane ramy czasowe monografii ujmują okres dokumentujący macedońskie zmagania o własną niezależność od wybuchu powstania antytureckiego 2 sierpnia 1903 r., które zakończyło się klęską ${ }^{3}$. Choć to rok 1913 obfitował $\mathrm{w}$ doniesienia prasowe, kiedy po drugiej wojnie bałkańskiej podpisany został traktat pokojowy w Bukareszcie, kładąc kres macedońskim marzeniom o samodzielności, to datą zamykającą pracę jest rok wybuchu I wojny światowej.

Autor zaczerpnął materiał z szerokiego zbioru prasy polskiej uwzględniając reprezentatywność dzienników oraz pism społeczno-politycznych, kulturalnych,

1 Mowa o wywiadzie z Goce Smilevskim (ur. 1975 w Skopje), autorze sztuk teatralnych i utworów prozą. W Polsce ukazała się jego powieść Rozmowa ze Spinoza (tłum. H. Karpińska, Oficyna 21, Warszawa 2004) oraz przełożona na ponad 30 języków, nagrodzona (m.in. nagroda Unii Europejskiej w zakresie literatury w roku 2010) kolejna książka Siostra Zygmunta Freuda (tłum. N. Łukomska, WAB, Kraków 2014). Przeprowadzony wywiad, Freud i Macedonia: Rozmowa $z$ Goce Smilevskim, ukazał się na stroniee internetowej: http://balkanistyka.org/ - dostęp 15.09.2015.

2 K. Stępnik, Macedonia w prasie polskiej (1903-1914), Wydawnictwo UMCS, Lublin 2014, ss. 285, il.

3 Powstanie przeszło do historii macedońskiej pod nazwą powstania ilindeńskiego od imienia św. Iliji, którego czci się w prawosławiu 2 sierpnia. W tradycji bułgarskiej znane jest jako powstanie ilindeńsko-preobrażeńskie. W dniu Przemienienia Pańskiego (Preobrażenie) 19 sierpnia walki zbrojne rozszerzyły się o tereny Tracji Adrianopolskiej. Zob.: T. Wasilewski, Historia Bułgarii, Ossolineum, Wrocław 1988, s. 211-212. 
ludowych, wyznaniowych czy podróżniczych. Przyjąwszy ściśle określony wycinek czasu, przejrzał prasę, która ukazywała się w Krakowie, Lwowie, Warszawie, Poznaniu i Wilnie. Zauważył przy tym, iż o kwestii macedońskiej pisano nie tylko w związku $\mathrm{z}$ wydarzeniami, do których dochodziło na ziemiach macedońskich, ale również w kontekście istotnych zdarzeń rozgrywających się na Półwyspie Bałkańskim - tym samym samoistna kwestia macedońska z czasem przekształciła się w kontekstową. Jak zastrzegł przy opisie przyjętej metody badawczej K. Stępnik, monografia nie jest jednak pracą z zakresu medioznawstwa, która miałaby opisywać procesy kształtowania rynku prasowego (choć Autor w pewnych momentach odnotowuje koniunkturalne zachowanie niektórych redakcji w odniesieniu do tematyki bałkańskiej). Główne zainteresowanie skoncentrował na analizie zawartości i formach artykulacji - od rubryk informacyjnych, poprzez komentarze i nowatorskie wówczas wywiady, do popularyzowanej ówcześnie formy reportażu.

Dokonana analiza pozwoliła dostrzec duże zainteresowanie problematyką macedońską w prasie, a także specyfikę polskiej recepcji wypadków na ziemiach macedońskich, wskazując, iż wydarzenia, które miały miejsce ponad 100 lat temu i zostały opisane, mają istotne znaczenie dla współczesnej refleksji na temat Bałkanów. Natomiast sam opis pozornie dawno przebrzmiałych spraw jest nader aktualny dla zrozumienia dzisiejszych scenariuszy politycznych, kiedy mogą się ujawnić nie tylko nierozwiązane problemy regionu, ale także polityka prowadzona przez liczące się na arenie międzynarodowej państwa.

Jak zauważył badacz, materiał $\mathrm{z}$ okresu powstania ilindeńskiego pojawiający się w prasie dowodzi, że to korespondenci prasy europejskiej w niemałym stopniu przyczynili się do stworzenia politycznego wizerunku Macedonii. Próby zainteresowania czytelników ziemiami macedońskimi, które u progu XX wieku z polskiej perspektywy były nieznane i egzotyczne, znalazły swój sensacyjny materiał właśnie w trwającym tam powstaniu antytureckim 1903 r., stając się tematem prasowym, budzącym takie zaciekawienie, gdyż jak napisał K. Stępnik: „w końcu sensacja jest nerwem dziennikarstwa, a w tym przypadku kierował się on w stronę kraju, którym nikt by się nie zainteresował, gdyby nie wybuch buntu" (s. 33).

Skrupulatna lektura zgromadzonego materiału pozwoliła Autorowi na ukazanie zróżnicowanego sposobu pisania o Macedonii i następujących tam po sobie zdarzeniach. Dotyczył on nie tylko braku albo nadmiaru dystansu do podawanych treści, ale także zróżnicowania na poziomie leksyki. W ten sposób odzwierciedlały się protureckie, prorosyjskie lub prohabsburskie wpływy polityczne, które oddziaływały na kształt zamieszczanych wiadomości. W zależności od miejsca publikacji reprezentowane były opcje polityki zagranicznej poszczególnych mocarstw. Prasę warszawską, podobnie galicyjską czy poznańską, określała „dzielnicowa racja stanu”, czyli stosunek do zaborcy, choć w pierwszej fazie informowania o zajściach na ziemiach macedońskich opierała się ona przede wszystkim na doniesieniach agencyjnych. I tak na przykład prasa galicyjska (lwowska i krakowska) oddawała stanowisko rządu Austro-Węgier. Odmienne nastawianie do zdarzeń macedońskich przekazywane było 
w prasie poznańskiej. Jak zauważył badacz, wynikało to z nieustannej konfrontacji polskiej opinii publicznej z władzami niemieckimi, co przyczyniło się do stworzenia trwałego fundamentu pod antygermanizm. $Z$ tego też powodu gazety poznańskie nie wtórowały polityce zagranicznej Berlina, a w ocenie wydarzeń znajdowały uznanie dla posunięć Rosji i stawiały się w pozycji wyraźnej słowiańskiej konfrontacji wobec niemieckiego punktu widzenia. O ile prasa galicyjska, odnosząc się do powstańców 1903 r., używała określeń „banda”, „bandyci”, o tyle w prasie poznańskiej częściej można było znaleźć określenia „rewolucjonista” lub „powstaniec”.

Wraz z rosnącym zainteresowaniem tym regionem niektóre z redakcji, odpowiadając na czytelnicze zapotrzebowanie źródłowe, zamieszczały oryginalne korespondencje z Bałkanów nadsyłane przez Józefa Fruzińskiego-Beja, Zygmunta Stefańskiego, Antoniego Piotrowskiego, Jana Grzegorzewskiego, Jana Ursyna-Zamarajewa, Gustawa Hertla czy duchownych pracujących na Bałkanach, którzy swe teksty zamieszczali na łamach „Misji Katolickich”. Do ich wypowiedzi odnosił się badacz, wskazując nie tylko na rosnące zainteresowanie tą przestrzenią terytorialną, ale również na kształtowanie polskiej opinii publicznej. Jak zauważył, sytuacja w tej części kontynentu ukazywana była także w zamieszczanych komentarzach. Poddał więc szczegółowej analizie teksty z opiniami L. Bzury, Bohdana Wasiutyńskiego, Władysława Studnickiego czy Adama Krzyżanowskiego, zwracając uwagę na materiały, do jakich się odwoływali w swoich artykułach i jakie stanowiska polityczne reprezentowali. Wskazał także na krytycyzm piszących wobec niewiarygodności istniejących danych statystycznych, którymi dla uzasadnienia swoich racji mieli posługiwać się czy to Bułgarzy, Serbowie, czy Grecy.

Autor z powodzeniem nakreślił wszechstronny obraz Macedonii, odsłaniając racje różnych stron, podłoże konfliktów, odmienne punkty widzenia. Słusznie przy tym uczynił, rezygnując z aluzji i widocznych analogii do historii końca wieku XX i początku wieku XXI. Trafnie zwrócił uwagę, iż przedstawienia prasowe stanowią rodzaj narracji historycznej wytwarzanej przez dziennikarzy i adresowanej do opinii publicznej, kształtując jej sposób postrzegania świata. Prasowy „zapis” o wydarzeniach na ziemiach macedońskich sprzed ponad stulecia wykazuje pewne pole wspólnotowe z monografią Dyskursy o Macedonii innych polskich badaczy - uznanego lingwisty Macieja Kawki oraz politologa i specjalisty od komunikacji masowej Pawła Płanety - którzy obok dyskursu językowego, literackiego i symbolicznego uwzględnili badania nad amerykańskim i polskim dyskursem prasowym o Macedonii w latach 1991-2012. Tym samym odnieśli się do czasów najnowszych, koncentrując się na okresie ponad dwudziestu lat, kiedy realizował się, zniweczony przez wojny bałkańskie, macedoński sen o własnej niezależności ${ }^{4}$. Gromadząc teksty poświęcone Macedonii, uczeni zbadali m.in. częstotliwość występowania związków wyrazowych, których cechy charakterystyczne odzwierciedlały istotę problemów współczesnego państwa. Okazało się, iż najsilniejsze, w jakie wchodzi grupa wyrazów wskazujących

4 M. Kawka, P. Płaneta, Dyskursy o Macedonii, Wydawnictwo Uniwersytetu Jagiellońskiego, Kraków 2013, ss. 314. 
na „macedońskość”, stanowią połączenia $\mathrm{z}$ aspektem etnicznym oraz albańskim, a w dalszej kolejności z greckim. Dało to asumpt Autorom książki do przedstawienia czytelnikom szczególnie tych problemów, które dla Macedonii i jej mieszkańców mają wymiar decydujący o ich poczuciu odrębności i tożsamości narodowej, a których przezwyciężenie leży w interesie nie tylko samych Macedończyków, ale także pozostałych mieszkańców Europy.

Świat nauki - podejmujący „temat niszowy”, jakim dla publicystów wydaje się problematyka macedońska - uzyskał też inną, bardzo cenną i ważną pracę. Tym razem jest to monografia Albańczycy w Macedonii 1944-2001, wybitnej znawczyni historii Macedonii Ireny Stawowej-Kawki ${ }^{5}$. I choć problematyka zarysowana w tytule sprowadza odbiorcę do określonego obszaru i okresu, to jednak ta właśnie monografia stanowi przykład gruntownie przygotowanego studium ukazującego istnienie konfliktu cywilizacji, z jakim w każdej chwili mogą zmierzyć się kraje Europy Zachodniej. Uczona skrupulatnie, $\mathrm{z}$ doskonałą znajomością źródeł, zachowując do nich krytyczny dystans badawczy ukazała, w jaki sposób i w jakich okolicznościach historycznych narastał konflikt etniczny, który, choć miał swoje apogeum w roku 2001 i w efekcie został zażegnany, to jednak może wybuchnąć $\mathrm{z}$ nową siłą, zmieniając porządek na Bałkanach. Autorka podjęła udaną próbę wytłumaczenia podłoża antagonizmu pomiędzy Macedończykami a Albańczykami, zwracając szczególną uwagę na doktrynę multietniczności, która napotkała w Macedonii poważne trudności, prowadząc do utworzenia etnicznych wysp, odizolowanych od reszty społeczeństwa, a nastawionych na zaspokajanie swych żądań, kolejnych roszczeń i potrzeb. Sytuacja, kiedy Macedończycy wychodząc z komunistycznych struktur starali się modernizować państwo i zaistnieć na mapie politycznej Europy, ujawniła konflikty, które elity rządzące próbowały rozwiązać na drodze stopniowych ustępstw wobec Albańczyków. Ci, stosując radykalne metody, ubiegali się o równorzędny status nie tylko w zakresie języka, kultury i nauki. Zasady sprawiedliwości w konflikcie albańsko-macedońskim, jakie miały sankcjonować ustalenia porozumienia zawartego w Ochrydzie w 2001 r., tak by zatrzymać krwawe starcia i trwale usunąć istniejące między nimi nieporozumienia i sprzeczności, stały się, zgodnie z wykładnią Stefana Wolffa, swoistym przykładem zarządzania konfliktem ${ }^{6}$.

Autorka, naświetlając narastanie zjawiska radykalizacji albańskich roszczeń, dokonała krytycznej analizy zarówno albańskich, jak i macedońskich materiałów źródłowych. Posłużyła się dokumentami instytucji i gremiów międzynarodowych, które pełniły funkcje rozjemcze $w$ konflikcie. Zauważyła przy tym brak kompleksowych monografii i opracowań dotyczących sytuacji Albańczyków w Macedonii, choć ośrodki badawcze po podpisaniu porozumień ochrydzkich dopiero z czasem podjęly trud naukowych analiz.

5 I. Stawowy-Kawka, Albańczycy w Macedonii 1944-2001, Wydawnictwo Uniwersytetu Jagiellońskiego, Kraków 2014, ss. 406, fot., tab., mapy.

6 S. Wolf, Ethnic Conflict: A Global Perspective, Oxford 2005. Podaję za I. Stawowy-Kawka, ibidem, s. 11. 
Wprowadzając czytelnika w sytuację Macedonii lat 1944-2001, I. Stawowy-Kawka przedstawiła dzieje wcześniejszych przesiedleń i migracji Albańczyków, ich sytuację w okresie dominacji Imperium Osmańskiego oraz stopniową asymilację w świecie islamu. W II połowie XVI wieku rozpoczęła się migracja tej ludności na tereny zajmowane przez Słowian, a u jej podłoża leżała trudna sytuacja ekonomiczna w tej części Bałkanów. Osiedlanie się Albańczyków w Kosowie i w zachodniej Macedonii w wiekach XVII i XVIII stawało się dla władz w Stambule skuteczną islamską zaporą w Europie. Przyjmowanie przez nich dominującego wyznania stawiało Albańczyków w pozycji uprzywilejowanej. Wykorzystując zachowane świadectwa przechowywane w różnych zbiorach (m.in. w monasterze pod wezwaniem św. Jovana Bigorskiego) Autorka zauważyła, że poza Albańczykami przechodzącymi na islam, przypadki konwersji zostały odnotowane także pośród ludności prawosławnej. Początkowo czynił tak jeden z przedstawicieli rodziny, chroniąc w ten sposób pozostałych jej członków przez uzbrojonymi grupami Albańczyków. Tak pojawiła się grupa Słowian, zwana Torbeszi, wyznająca islam, która nie posługiwała się ani językiem albańskim, ani tureckim.

Konfrontacja źródeł i opracowań, do których dotarła uczona wskazuje, iż pewne daty i interpretacja faktów uzależnione są od postaw autorów reprezentujących różne opcje bądź posługujących się innymi materiałami źródłowymi. Jak zauważa, za początek albańskiego ruchu narodowego niektórzy badacze przyjmują rok 1878, kiedy Liga Albańska wydała dokument programowy mówiący o przyszłych granicach postulowanego państwa, natomiast autorzy albańscy wiążą go $\mathrm{z}$ rokiem 1836, w którym opublikowano zbiór wierszy poety i folklorysty Jeronima de Rady Këngët e Milosaos. Powstanie państwa albańskiego w 1913 r. w okrojonych granicach dla niektórych uczonych stanowiło wynik gry mocarstw, które kierowały się przede wszystkim własnymi interesami na Bałkanach i podjęły skuteczną na tym etapie próbę zapobieżenia wzrostowi terytorialnej potęgi Serbii. Zgoda Włoch i Austro-Węgier na utworzenie państwa albańskiego skutecznie temu zapobiegła, ale stała się początkiem kolejnych konfliktów. Badaczka wskazała, iż w ciągu swej powojennej historii aż do czasów obecnych Albańczycy powołują się na złe rozwiązanie mocarstw, które wytyczyły zasięg terytorialny ich państwa, pozostawiając poza jego granicami dużą część swojej ludności. Dostęp do wykorzystywanych opracowań pozwolił Autorce ukazać również postępującą mityzację ich własnej przeszłości, wyolbrzymianie poszczególnych wydarzeń historycznych i nadawanie im przez Albańczyków innego sensu, który, jak pisał przywołany przez nią albański pisarz Fatos Lubonja, podyktowany jest potrzebą dumy z własnego narodu ${ }^{7}$.

Na podstawie analizy źródeł wykorzystanych przez I. Stawowy-Kawkę zauważyć można też zmiany leksykalne w sposobie pisania o sytuacji Albańczyków i określania niektórych procesów, jakie zachodziły w ich historii związanej z terytorium Macedonii. Przykład jednego $\mathrm{z}$ nich stanowią przesiedlenia do Turcji $\mathrm{w}$ latach 1951-1958, kiedy migracja objęła zamieszkujących tam Turków, Cyganów i ludność

7 F. Lubonja, Albania - wolność zagrożona. Wybór publicystyki z lat 1991-2002, Sejny 2005. Podaję za I. Stawowy-Kawka, op. cit., s. 27. 
albańską. I tak autorzy macedońscy podkreślają jej dobrowolny charakter, twierdząc, iż Albańczycy nie widzieli dla siebie perspektyw życia na odpowiednim poziomie w Ludowej Republice Macedonii i możliwości pełnego uczestnictwa w praktykach religijnych. Natomiast współcześni autorzy albańscy, opisując zjawisko wędrówki etnosu poza granice Macedonii, posługują się terminami „wysiedlenia” oraz „deportacja”, wskazując na jej przymusową naturę, gdyż to Albańczycy byli zmuszani do przyjmowania tożsamości tureckiej, aby zmienić miejsce swego zamieszkania.

Analiza materiałów kartograficznych z okresu albańskiego ruchu narodowego ujęta w monografii dokumentuje zróżnicowany sposób ukazywania zasięgu żywiołu albańskiego na terytorium Macedonii. W zależności od tego, jaki interes w danym momencie był reprezentowany, przewagę ludności albańskiej oddawały mapy włoskie i austriackie, natomiast na dominację ludności słowiańskiej tego terytorium wskazywały mapy bułgarskie, rosyjskie i serbskie. Podobnie konfrontacja danych statystycznych z różnych źródeł, a odnoszących się do ludności albańskiej na spornych terenach u progu wieku XX wykazała, iż inne dane przekazywały statystyki greckie, inne zaś bułgarskie. Jak zauważyła Autorka, nie są one precyzyjne, gdyż nie określają w sposób właściwy narodowości - dla całej ludności słowiańskiej obszaru Bułgarzy stosowali typologię ludności bułgarskiej, natomiast Grecy posługiwali się etnonimem Słowianie. Badaczka odniosła się również do materiałów albańskich i włoskich, gdyż to Włochy w okresie międzywojennym miały być gwarantem powstania wielkiej Albanii. Zmiany granic, jakie następowały w okresie II wojny światowej, wynikały ze wspierania przez Albańczyków faszystowskich Włoch bądź też z rodzącego się z inicjatywy partyzantki jugosłowiańskiej albańskiego ruchu komunistycznego. Odsłaniane po latach dokumenty ujawniają kulisy ustalania granic Albanii po II wojnie światowej. Ich nowe ramy nie przyniosły uspokojenia w tej części Bałkanów, sprawiając, że dla dzisiejszej ludności albańskiej w Kosowie i zachodniej Macedonii problem ich państwowej przynależności nadal pozostaje otwarty.

Wykorzystane przez Autorkę dane statystyczne pozwoliły także na ukazanie sytuacji demograficznej Albańczyków w przeciągu omawianego okresu oraz wskazały przyczyny ich rosnącej liczebności. Najważniejszą pozostawał wysoki przyrost naturalny, ich napływ z Kosowa-Metohiji do Macedonii oraz określanie jako ludności albańskiej muzułmanów innych narodowości, a wśród nich m.in. Turków i Macedończyków. Zamieszczone w monografii tabele ilustrują, iż faktycznie przyrost naturalny Albańczyków znacznie przekraczał średnią narodzin wśród słowiańskiej ludności Macedonii. Nie bez znaczenia dla położenia Albańczyków w tym kraju pozostawała też doktryna „braterstwa i jedności” w okresie trwania federacji jugosłowiańskiej. Jak dostrzegła Autorka, opracowania albańskie obciążają Macedonię za terror wobec swego etnosu w okresie powojennym. W tym kontekście przypomniała, iż przemoc stosowana w titowskiej Jugosławii dotyczyła mieszkańców wszystkich tworzących ją republik. Tym samym złożony obraz sytuacji nie dotyczył li tylko Macedonii, ale wynikał z uwarunkowań systemowych w państwie jugosłowiańskim, kiedy wszyscy obywatele, także ludność muzułmańska Macedonii, byli 
zmuszani do podporządkowania się nowemu porządkowi. Wskazała przy tym na istnienie dwóch form integrowania Albańczyków w komunistycznej rzeczywistości - zarówno poprzez zwykłą pracę, jak i drogą udziału w systemie agitacji i upowszechniania nowego ładu. Mimo założonego ateizmu państwa jugosłowiańskiego pozostawiono Albańczykom względną swobodę kultu, tak że albańscy funkcjonariusze partyjni swobodnie uczęszczali do meczetu. Specyfika ich środowiska, $\mathrm{z}$ hołdowaniem własnej tradycji sprawiała, iż rodzice ukrywali wiek swoich dzieci ze względu na konieczność realizowania wprowadzonego przez komunistyczne państwo obowiązku szkolnego. Wynikało to z przekonania, że nauczanie jest szkodliwe dla dziewcząt i zupełnie niekonieczne dla chłopców.

Rozpad Jugosławii, która przez kilka dekad stanowiła gwarancję istnienia Macedonii (w formie Ludowej Republiki Macedonii) ujawnił problemy, jakie wraz $\mathrm{z}$ ustanowieniem państwowej samodzielności zgłaszały nie tylko sąsiednie kraje, ale także Albańczycy żyjący w jej granicach. Eskalacja konfliktu albańsko-macedońskiego, do jakiej doszło w 2001 r., znalazła swoje uzasadnienie zarówno w perspektywie albańskiej, jak i macedońskiej. W Skopje uważa się, że przyczyną był masowy napływ Albańczyków z Kosowa i Albanii do Macedonii dla poprawy swego bytu. Ich przywiązanie do terenów, na których się urodzili i żyli, identyfikowanie się z Albanią czy Kosowem albo przywiązanie do idei jedności albańskiej dowodziły zaś braku szczególnych związków z Macedończykami. Natomiast dla Albańczyków eskalacja konfliktu wynikała $\mathrm{z}$ faktu ich statusu jako mniejszości narodowej i dyskryminacji we wspólnym państwie. Dlatego też kroki, jakie podejmowali, miały prowadzić do uzyskania równych praw z Macedończykami. W związku z tym Forum Albańskich Intelektualistów zgłaszało postulaty uznania języka albańskiego, tak by stał się obok języka macedońskiego obowiązującym na terytorium Macedonii jako urzędowy oraz domagało się konstytucyjnych gwarancji równego dostępu do szkół i stanowisk. Aktywność polityczna Albańczyków kierowała się przy tym ku tworzeniu ich autonomicznych terytoriów - taką była próba utworzenia Republiki Ilirydy w okolicy miasta Struga czy próby oderwania od zachodniej części Macedonii terytoriów przez nich zamieszkiwanych. Kontaminacja wydarzeń w Kosowie, Dolinie Preševa i w zachodniej Macedonii, ujawniła widmo „wielkiej Albanii”, jaka mogłaby powstać na bazie etnicznej, obejmującej Albanię, Kosowo oraz zachodnią część państwa. Analiza sytuacji geopolitycznej Macedonii przestawiona przez I. Stawowy-Kawkę ukazała zagrożenia, przed jakimi stanęło młode państwo w obliczu interwencji NATO w Kosowie. Ujawniła też złożoność relacji międzysąsiedzkich w poszukiwaniu sojuszy gwarantujących stabilizację także w obliczu pretensji zgłaszanych przez Greków sugerujących zmianę nazwy państwa na neutralną etnicznie jako Wardarska Republika, Centralna Bałkańska Republika czy Słowiańsko-Albańska Macedonia. Podjęcie walki zbrojnej, taktycznie podobnej do tej, jaką Albańczycy prowadzili w Kosowie, miała się $\mathrm{w}$ ich przypadku okazać jedynym skutecznym sposobem na zapewnienie pełni praw. Kres zbrojnej fazie konfliktu, który rozwijał się w okresie od lutego do czerwca 2001 r., położyło dopiero porozumienie wyne- 
gocjowane w Ochrydzie, a parafowane w Skopje 13 sierpnia 2001 r. przy mediacji sił międzynarodowych.

I. Stawowy-Kawka nie ograniczyła się w swej pracy tylko do opisania zjawisk $\mathrm{w}$ relacjach albańsko-macedońskich zwieńczonych zawarciem dwustronnego porozumienia. $Z$ perspektywy ponad dziesięciu lat od tego wydarzenia podjęła próbę opisu, w jaki sposób układa się koegzystencja obu nacji, gdy faktycznie doszło do utworzenia dwunarodowej struktury macedońsko-albańskiej, a polityczne waśnie przeszły w fazę walki na symbole. Macedończycy w skupiskach, które zamieszkują, stawiają krzyże, natomiast Albańczycy w każdej swojej wsi czy osadzie budują meczety $z$ dominującymi nad nimi minaretami. Obie strony wykorzystują przy tym swoje symbole narodowe, a istotną rolę odgrywają pomniki i obiekty upamiętniające przeszłość, stając się przykładem sporu o własną tożsamość.

Monografia Ireny Stawowy-Kawki poświęcona wzajemnym relacjom albańsko-macedońskim jest pierwszym tak wnikliwym studium obrazującym przyczyny i narastanie konfliktów międzyetnicznych, które mogą dosięgnąć także inne, zróżnicowane rejony Europy, a sytuacja Macedonii, niewielkiego kraju na Bałkanach, może stanowić swoiste ostrzeżenie przed prowadzeniem polityki, w której realizowane są jedynie partykularne interesy poszczególnych grup.

Inny charakter ma nieco wcześniejsza praca tej samej Autorki, powstała we współautorstwie z Kateriną Todoroską, poświęcona bilateralnym stosunkom polsko-macedońskim w latach 1991-2011. Stanowi ją zbiór dokumentów z tego okresu ujawniających dwustronne kontakty między państwami ${ }^{8}$. Jak we wstępie piszą Autorki, prezentacja materiału jest wynikiem spotkań naukowych na Uniwersytecie Jagiellońskim oraz w Instytucie Historii Narodowej w Skopje, podczas których historycy, politolodzy, lingwiści, kulturolodzy podejmowali kwestie związane z istotnymi problemami we współpracy obu krajów. Ramy czasowe opublikowanych aktów odnoszą się do ważkich dla Macedonii wydarzeń, czyli od roku 1991, kiedy Macedonia proklamowała swą niepodległość, do roku 2011, kiedy świętowano jej 20. rocznicę. Bilateralną współpracę obu krajów realizowano z powodzeniem zarówno w sferze gospodarczej, politycznej, dyplomatycznej, jak i kulturalno-naukowej. Autorki wyboru dokumentów zwróciły uwagę, iż w pierwszych latach samodzielności Macedonii współpraca oparta była na bazie wcześniej obowiązujących aktów prawnych zawartych pomiędzy Jugosławią a Polską, chociaż istniały w pewnym zakresie wcześniejsze umowy dwustronne podpisane pomiędzy Polską a Republiką Macedonii w strukturach Jugosławii. W zamieszczonych tabelach przypomniały nazwiska dyplomatów obu stron, którzy w pewnym sensie kształtowali dwustronną politykę. Podkreśliły, iż nawiązanie stosunków dyplomatycznych służyć miało nie tylko ochronie mieszkających w Polsce Macedończyków czy Polaków w Macedonii, ale także wzajemnemu wsparciu w staraniach o przyjęcie do struktur NATO i Unii Europejskiej. Zaprezentowany zbiór dokumentów podany w obu wersjach języko-

8 Билатералните полско-македонски односи 1991-2011, приредувачи И. Ставови-Кавка, К. Тодороска, т. 1, Менора, Скопје 2013, с. 240. 
wych, polskiej i macedońskiej, a bazowe z nich także po angielsku, jest dowodem dobrze układających się relacji pomiędzy Polską i Macedonią. Zawarty w tomie źródłowy materiał stanowić może podstawową bazę do podjęcia dalszych badań, podobnie jak ujawnione ledwie kilka lat wcześniej, a przez lata owiane tajemnicą materiały dotyczące macedońskich uciekinierów, którzy od października $1948 \mathrm{r}$. znajdowali swe schronienie w Polsce. Opublikowane w wersji polskiej i macedońskiej dzięki staraniom Petre Nakovskiego i Naczelnej Dyrekcji Archiwów Państwowych materiały odsłoniły tematy do tej pory pieczołowicie skrywane.

Omówione skrótowo prace dowodzą, iż tematykę macedońską podejmują badacze różnych dyscyplin naukowych. Prace polskich uczonych doskonale wypełniają białe plamy w wiedzy o odległym kraju na południa Europy, a poruszana przez nich problematyka nie jest tematem niszowym.

\section{The fields of interest in Macedonia-related issues in Poland: an academic literature review}

This review article presents the academic literature dedicated to Macedonia published over the last few years by the Polish research community. It discusses the monograph Macedonia in the Polish press (1903-1914) by Krzysztof Stępnik, expert in Polish political journalism and press discourse, as well as the study Discourses on Macedonia by Maciej Kawka, linguist, and Paweł Płaneta, political scientist and expert on mass communication; the article also refers to the collection of documents compiled and analysed by Irena Stawowa-Kawka and Katerina Todorovska. Much room was dedicated to the treatise Albanians in Macedonia from 1944 to 2001 by eminent expert in the history of Macedonia Irena Stawowa-Kawka. It was pointed out that, although dedicated to the young Balkan state, this monograph was an excellent example of a study portraying the various processes taking place between diverse ethnic groups and suggesting the existence of a clash of civilisations, which Western Europe might face at any moment.

The works discussed brought in-depth analyses, which not only showed the specificity of the Polish interpretation of the events that took place on Macedonian soil in the past, but also offered a glimpse on the processes occurring today. While maintaining a critical distance in relation to the sources used, the authors portrayed Macedonia in its key historical moments (the Balkan wars, the formation of Macedonia within the Yugoslav Federation, the declaration of independence in 1991, the Ohrid Agreement from 2001) and in the most recent times. The current state of affairs in Macedonia, including its ethnic issues and its efforts towards joining both the EU and NATO, obliges this country to seek various alliances. This tendency is reflected in the collection of documents on the bilateral Polish-Macedonian cooperation.

The publications presented in this article characterise the most important issues of the Macedonian state, arguing that this country remains an important research subject to be undertaken by Polish scholars of various disciplines.

Translated by Jakub Perliński

9 Македонските бегалиц во Полска. Документи. 1948-1975. Проблеми на воспитанието и образованието на деияата и на младината, т. 1-2, избор, превод, вовед, ред. П. Наковски, Државен архив на Република Македонија, Дирекција на државните архиви Полска, Скопје 2008. O tym, iż temat macedońskich uchodźców w Polsce jest stopniowo odsłaniany, świadczy praca, która ujrzała światło dzienne z chwilą oddawania tego tekstu do druku: A. Kurpiel, Cztery nazwiska, dwa imiona. Macedońscy uchodźcy wojenni na Dolnym Ślasku, Nauka i Innowacje, Poznań 2015. 


\section{Македонская проблематика в Польше - круги интересов. Научные публикации}

В рецензионной статье были представлены научные публикации, посвященные Македонии, созданные в польской исследовательской среде в течение нескольких последних лет. В ней рассматриваются: монография „Македония в польской прессе (1903-1914)”, написанная знатоком польской политической публицистики и дискурса прессы Кшиштофа Стемпника, „Дискурсы о Македонии” - совместное исследование лингвиста Мацея Кавки и политолога, а также специалиста по массовой коммуникации Павла Планеты, а также сборник документов в соавторской обработке Ирены Ставовой-Кавки и Катерины Тодороской. Особенно много места было уделено работе „Албанцы в Македонии 1944-2001” выдающегося знатока македонской истории Ирены Ставовой-Кавки. Было замечено, что именно эта монография, хотя посвященная молодой балканской стране, является примером исследования, показывающего процессы, происходящие между разнообразными этносами и существование конфликта цивилизаций, с каким в любой момент могут столкнуться страны Западной Европы.

Рассмотренные работы принесли подробные анализы, которые не только обнаружили специфику польского восприятия прошлых событий, которые имели место на македонских землях, но и взгляда на современно происходящие процессы. Их авторы тщательно, соблюдая критическую исследовательскую дистанцию к использованным источникам, показали историю Македонии в ключевых для нее исторических моментах (Балканские войны, образование Македонии в рамках Югославской федерации, обретение независимости в 1991г., Охридский договор 2001г.) и в новейшем времени. Настоящее Македонии, с сопутствующими ей этническими проблемами, с усилиями, предпринимаемыми для вступления в структуры НАТО и ЕС, возлагает на это государство необходимость образования союзов, что отразилось в сборнике документов, посвященных билатеральному польско-македонскому сотрудничеству.

Представленные публикации показывают самые существенные проблемы Македонии, доказывая, что македонская тематика, поднимаемая польскими учеными разных научных дисциплин, остается существенной исследовательской проблемой.

Перевод Агнешка Поспишыль

\section{Bibliografia:}

Kawka Maciej, Płaneta Paweł. 2013. Dyskursy o Macedonii. Kraków: Wydawnictwo Uniwersytetu Jagiellońskiego.

Kurpiel Anna. 2015. Cztery nazwiska, dwa imiona. Macedońscy uchodźcy wojenni na Dolnym Ślasku, Poznań: Nauka i Innowacje.

Moroz-Grzelak Lilla. 2015. Freud i Macedonia: Rozmowa $z$ Goce Smilevskim. http://balkanistyka. org/ - dostęp 11.09.2015.

Smilevski Goce. 2004. Rozmowa ze Spinoza, tłum. H. Karpińska. Warszawa: Oficyna 21.

Smilevski Goce. 2014. Siostra Zygmunta Freuda, tłum. N. Łukomska. Kraków: WAB.

Stawowy-Kawka Irena. 2014. Albańczycy w Macedonii 1944-2001. Kraków: Wydawnictwo Uniwersytetu Jagiellońskiego.

Stępnik Krzysztof. 2014. Macedonia w prasie polskiej (1903-1914). Lublin: Wydawnictwo UMCS Wasilewski Tadeusz. 1988. Historia Bułgarii. Wrocław: Ossolineum.

Наковски Петре (избор, превод, вовед, ред.). 2008. Македонските бегалии во Полска. Документи. 1948-1975. Проблеми на воспитанието и образованието на децата и на 
младината, t. 1-2. Скопје: Државен архив на Република Македонија, Дирекција на државните архиви Полска.

Ставови-Кавка Ирена, Тодороска Катерина (приредувачи). 2013. Билатералните полско-македонски односи 1991-2011, т. 1. Скопје: Менора.

Lilla Moroz-Grzelak - profesor w Instytucie Slawistyki PAN, badaczka literatury i kultury Słowian bałkańskich. W artykułach i monografiach (Aleksander Wielki a macedońska idea narodowa. Słowiańskie losy postaci antycznej; Bracia Słowianie. Wizje wspólnoty a rzeczywistość) podejmuje zagadnienia związane z przemianami ideowymi w ich kulturach. (lilamor@poczta.onet.pl) 